\title{
Agronomic performance of soybean with indeterminate growth habit in different plant arrangements
}

\author{
Daniel Augusto Silveira ${ }^{1}$, Beatriz Braga Silveira ${ }^{2}$, Cássio Egídio Cavenaghi Prete ${ }^{2}$, Carlos André Bahry $^{3}$ and \\ Maicon Nardino ${ }^{4}$
}

\author{
${ }^{1}$ Syngenta Proteção de Cultivos Ltda, Londrina, PR, Brasil. \\ ${ }^{2}$ Universidade Estadual de Londrina, Londrina, PR, Brasil. \\ ${ }^{3}$ Universidade Tecnológica Federal do Paraná, Dois Vizinhos, PR, Brasil. \\ ${ }^{4}$ Universidade Federal de Viçosa, Viçosa, MG, Brasil. \\ Correspondence to: nardino@ufv.br
}

\begin{abstract}
OPEN ACCESS
(c) The Author

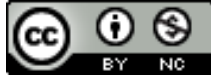

Submitted on October 25, 2020 Accepted on April 29, 2021 Early View on May 06, 2021 Final Publication on May 07, 2021 Author declares no conflict of interest KEYWORDS: Glycine max L. Paired-rows Plant population Spatial arrangement (Spatial arrangement

\section{ABSTRACT}

Plant arrangements are a practice that has remained constant for decades, with little research about soybeans, with contrasting rainfall conditions. The purpose of this work was to evaluate the agronomic performance of indeterminate soybean with variation for the plant arrangements, populations and in cultivation of crops. The research was conducted in Arapongas-PR with an experimental design of randomized blocks, organized in a $6 \times 3 \times 2$ factorial scheme, with four replications. The variation factors were six populations $(100,200$, $300,400,500$ and 600 thousand plants ha $\left.{ }^{-1}\right)$, three plant arrangements $(0.25 \mathrm{~cm}, 0.50 \mathrm{~cm}$ and $0.25 \times 0.50 \mathrm{~cm}$ in paired-rows) and two cultivation of crops. The statistical analysis sought to evaluate the interactions and break down the simple effects and the main effects. Row spacing influenced the variables grain yield, height of the first pod insertion, plant height and leaf area index. Populations with up to 300 thousand plants reached the highest levels of grain yield. The plant arrangement for the paired-rows is superior to traditional spacing, with $4,732 \mathrm{~kg} \mathrm{ha}^{-1}$ for the spacing $0.25 \times 0.50 \mathrm{~m}, 3,817 \mathrm{~kg} \mathrm{ha}^{-1}$ for the spacing $0.50 \mathrm{~m}$ and $3,628 \mathrm{~kg}$ $\mathrm{ha}^{-1}$ for the spacing $0.25 \mathrm{~m}$.

\section{Highlighted Conclusions}

1. The agronomic performance of the CA7442 RR1 soybean cultivar, with undetermined habit, is influenced by the spatial arrangement, by the plant population.

2. There is a tendency to reduce grain yield in higher populations under water stress conditions.

3. The arrangement of paired-rows in relation to single-rows revealed grain yield $20 \%$ higher for harvests with normal precipitation.
\end{abstract}

\section{INTRODUCTION}

Soybean is one of the most relevant crops in the world and in Brazil, and its evolution occurred through the expansion of areas requiring numerous technological advances, however, in the last ten years, mean productivity has stabilized around 3 ton ha ${ }^{-1}$. Conab's estimates for the 2020/21 harvest indicate a prospect of an increase of 2 million tons, motivated by prices in Brazil, which corresponds to $7.1 \%$, with estimates of a $4.4 \%$ increase in productivity and $2.5 \%$ in area (Conab 2020). Conab's estimate is that Brazil will continue to be the second largest soybean producer in the world with 133,673 million tons.

The spatial plant arrangement can directly interfere in the speed of closing of row spacing (Shaw and Weber 1967, Heiffig et al. 2006), in the production of dry mass because depending on the morphological characteristics of the plant, it can produce a greater amount of leaves, increasing the photosynthetic leaf area (Cox and Cherney 2011), in the soy architecture itself (more branched plants) (Cox et al. 2010), in the severity of diseases (microclimate formation) (Lima et al. 2012) and in the component most important production, in other words, in grain yield (Rambo et al. 2003, Rambo 2004, Bruin and Pedersen 2008, Hanna et al. 2008). These impacts are due to the intraspecific competition that directly affects the capture of environmental resources such as water, light, nutrients and $\mathrm{CO}_{2}$. 
The use of spacings in paired-rows has been widely studied in the culture of corn, where great responses are observed. Paired or double rows have been adopted in order to increase productivity, through better light interception and, consequently, increasing the photosynthetic activity of the crop (Novacek et al. 2013).

In soybean cultivation, the adoption of double rows can lead to a reduction in plant size without interfering in crop productivity, in this work Duarte et al. (2016) identified that, for the ANTA 82 variety, there was a response to the population increase regardless of the arrangement adopted. The main reason for the change in the plant arrangement, by reducing the distance rows, is to reduce the time for $95 \%$ of the incident solar radiation to be intercepted by the crop, and then, the amount of light captured per unit area and time is increased (Board et al. 1992).

In the double row planting system, the planting population is adjusted, aiming at the row spacing, freeing up spaces for light penetration. This arrangement modality can be considered as an agronomic practice that can increase grain yield with low cost of adoption. Higher yields can be obtained under the arrangement with two rows compared to planting in single spacings (Bruns 2011, Güllüllüoglu et al. 2016).

Another factor that interferes with the interception of solar radiation is what we call the leaf area index (LAl) that represents the relationship between the area of foliage and the surface of the soil it occupies and is variable according to plant species, climate, seasons and plant development stage (Heiffig et al. 2006). The increase in the $\mathrm{LAl}$, up to a critical value, also increases the interception of light and, consequently, liquid photosynthesis. Shibles and Weber (1965) also referred to the height of the LAI at the end of fruiting and the beginning of soy granulation, in addition to having observed two peaks in photosynthetic activity: the first at the time of full flowering of soy, to meet fertilization; the second, when granulation starts, when the presence of photoassimilates is necessary for the development of pods and grains inside.

The determination of vegetation indexes can also be carried out by means of spectral combinations of green coverage area. Many vegetation indexes are adopted to determine the relations of leaf area and soil cover areas, the Normalized Difference Vegetation Index (NDVI) can be used for several purposes, from satellite monitoring (Sellers et al. 1994), even in the evaluation of the spectral behavior of different soybean genotypes in different field conditions (Crusciol et al. 2013).

According to this scenario, the present study aimed to evaluate the agronomic performance of the CA 7442 RR1 soybean cultivar of indeterminate growth habit, in six plant populations, three spatial arrangements and two agricultural crops.

\section{MATERIAL AND METHODS}

Experimental material. The tests were conducted in two cultivation of crops, with experiment 1 in the 2013/14 crop and experiment 2 in the 2015/16 crop. Both experiments were conducted at Fazenda Gaúcha, located in the city of Arapongas - PR, with geographic coordinates $23^{\circ} 29^{\prime} 4^{\prime \prime} \mathrm{S}$ and ${ }^{510} 25^{\prime} 40^{\prime \prime} \mathrm{O}$, altitude of 831 meters above sea level.

Characterization of the place and management of the crop. The farm soil was identified as Latossolo Vermelho Distroférrico (Santos et al. 2006) and according to the analysis carried out it had the following elements and quantities before the implementation of the experiments: $\mathrm{pH}$ in $\mathrm{CaCl}_{2}: 5.23 ; \mathrm{C}\left(\mathrm{g} \mathrm{dm}^{-3}\right): 33.29 ; \mathrm{P}\left(\mathrm{mg} \mathrm{dm}^{-3}\right)$, Mehlich 1: 18.49; $\mathrm{K}^{+}\left(\mathrm{cmol}_{\mathrm{c}} \mathrm{dm}^{-3}\right)$, Mehlich-1: $0.78 ; \mathrm{Ca}^{+2}\left(\mathrm{cmol}_{\mathrm{c}} \mathrm{dm}^{-3}\right), \mathrm{KCl} 1 \mathrm{~N}: 5.31 ; \mathrm{Mg}^{+2}\left(\mathrm{cmol}_{\mathrm{c}} \mathrm{dm}^{-3}\right), \mathrm{KCl} 1 \mathrm{~N}: 2.22 ; \mathrm{Al}^{+3}$ $\left(\mathrm{cmol}_{\mathrm{c}} \mathrm{dm}^{-3}\right), \mathrm{KCl} 1 \mathrm{~N}: 0.00 ; \mathrm{H}^{+}+\mathrm{Al}^{+3}\left(\mathrm{cmol}_{\mathrm{c}} \mathrm{dm}^{-3}\right)$, SMP: $3.75 ; \mathrm{SB}\left(\mathrm{cmol}_{\mathrm{c}} \mathrm{dm}^{-3}\right): 5.81 ; \mathrm{V}-$ Base saturation index $(\%)$ : 55,01; M - Saturation index by Al+3 (\%): 0,00; CTC $\left(\mathrm{cmol}_{\mathrm{C}} \mathrm{dm}^{-3}\right): 10.55$.

The predecessor crop for soybeans was black oats (Avena strigosa L.). The fertilization in the sowing of black oats was adopted aiming at the cultivation system for the subsequent culture, with fertilization of $400 \mathrm{~kg} \mathrm{ha} 1$ of the fertilizer formulated 10-15-15. The sowing of soybeans for both harvests was the system of direct seeding, carried out in October of each year. The seed treatment used was carried out with Avicta 500FS products; Cruiser $250 \mathrm{FS}$ and Maxim Advanced in doses of 70,200 and $100 \mathrm{~mL}$ per $100 \mathrm{~kg}$ of seeds.

Climate conditions - characterization. The data of precipitation, maximum and minimum temperature of the first (2013/2014) and second crop (2015/2016) are shown in Figure 1.

Experiment design and treatment. Initially, a survey of the strange characteristics that were active or that could influence the results of the treatment effects was carried out, which, therefore, must be controlled partially or totally so that the results of the expression of the effects of the treatment design are reliable. The experiments were installed in a complete randomized block design, in a $3 \times 6 \times 2$ factorial scheme with four replications. The factors studied were: Factor A - three spatial arrangements of plants: $0.25 \mathrm{~m}, 50 \mathrm{~cm}$ and the combination $0.25 \times 0.50 \mathrm{~m}$; Factor B - six soybean plant populations $\left(100,200,300,400,500\right.$ and 600 thousand plants ha $\left.{ }^{-1}\right)$; Factor C analysis of the two cultivation of crops, conducted in 2013/2014 and 2015/2016. 

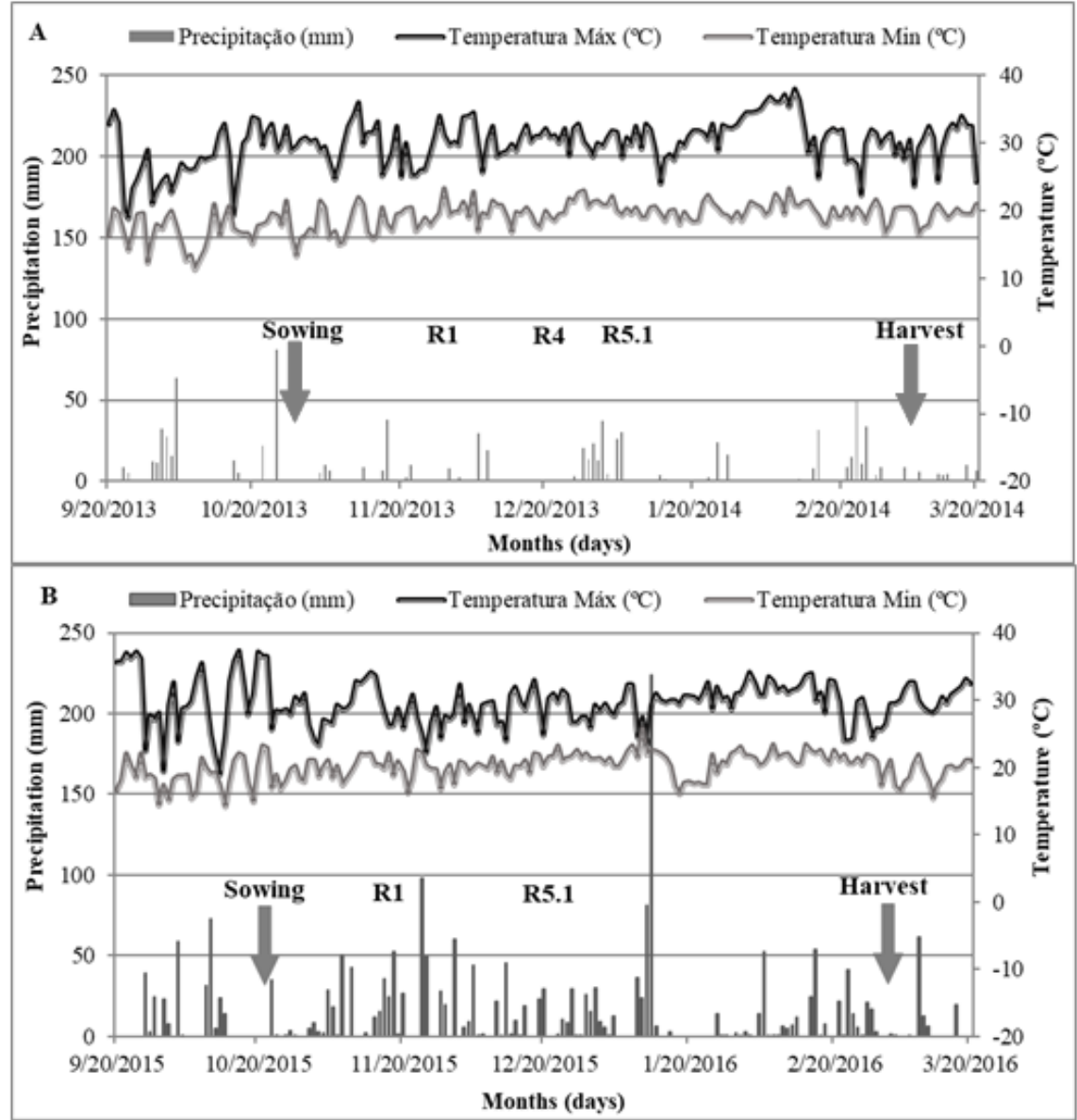

Figure 1. (A) Results of meteorological data for experiment one (1st experiment) in the period from 09/20/2013 to 03/20/2014. Sowing on October 30, 2013 - (B) Results of meteorological data for experiment two (2nd experiment) for the region of Arapongas-PR in the period from 09/20/2015 to 03/20/2016. Sowing on October 23, 2015. Source: IAPAR.

Cultivar CA7442 RR1 was used as for the study plant material (Table 1). The variables analyzed were described in the Chart 1 . The experimental unit consisted of 16 sowing rows, five meters long. For the first level of factor A $(0.25 \mathrm{~cm}$ arrangement), it was necessary to carry out two sowing in the same area with GPS equipment from the TRIMBOW model, model US-17 and autopilot.

Table 1. Description of the soybean cultivar used in the cultivation tests of $2013 / 2014$ and 2015/2016. Londrina, 2020.

\begin{tabular}{cc}
\hline Cultivar & CA 7442 RR \\
\hline Cycle & Precocious \\
Maturation group & 5.7 \\
Growth habit & Indeterminate \\
Thousand seed mass Sieve 5.5 & 145 grams \\
Hight plant & $0.66 \mathrm{~m}$ \\
Flower & White \\
Pubescence & Light brown \\
Hilum & Black \\
Lodging & Resistant \\
\hline Source: *Syngenta (2017). &
\end{tabular}

Statistical analysis. The experimental data obtained were subjected to homogeneity of variance tests (Levene test), error linearity, model additivity and normality of errors (Shapiro-Wilks test). After meeting the assumptions of the analysis of variation (ANOVA), the data were subjected to analysis of variance considering the three-factor mathematical model adopted in the experimental plan. In the presence of significance for interaction, the procedure adopted was to unfold the simple effects of the factors. In the absence of significance for interaction, the main effects of the factors were separated separately, the qualitative ones being compared by means test and the quantitative factor via linear regression (population) considering the probability of $5 \%$ of error. 
Chart 1. Description of the variables evaluated in the experiments.

\begin{tabular}{|c|c|c|c|}
\hline Obs & Variable & Unit & Description \\
\hline 1 & $\mathrm{PH}$ & $\mathrm{cm}$ & It was measured by measuring from the base of the plant to the end, performed on 10 plot plants. \\
\hline 2 & HIP & $\mathrm{cm}$ & Measured by the measure of insertion of the first pod to the upper end of the plant \\
\hline 3 & $\mathrm{ACM}$ & Notes & $\begin{array}{l}\text { Bedded plants were those with a slope greater than } 45^{\circ} \text { in relation to the soil surface. The lodging of } \\
\text { soybean plants was determined when the plants were in stage R7. The evaluation was made by } \\
\text { means of visual analysis, with scores given to the plots based on a scale of } 1 \text { ( } 0 \% \text { of bedded plants } \\
\text { in the plot) to } 9(100 \% \text { of bedded plants in the plot). }\end{array}$ \\
\hline 4 & LAI & $\mathrm{m}^{2} \mathrm{~m}^{-2}$ & $\begin{array}{l}\text { The determination of the leaf area index was carried out through the process of extracting the pixels } \\
\text { referring to the green areas of the plants. For this purpose, three plants were used per plot, } \\
\text { defoliated and photographed on a clean flat surface with a white background (BRILHADOR, 2013). }\end{array}$ \\
\hline 5 & NDVI & & $\begin{array}{l}\text { Normalized Difference Vegetation Index: the GreenSeeker equipment by Trimble - Hand Crop } \\
\text { Sensor was used, in the vegetative stage R5.3 through manual reading in the field. }\end{array}$ \\
\hline 6 & NPP & unit & $\begin{array}{l}\text { It was determined by counting the pods present in the entire plant, to measure this variable, one } \\
\text { meter of row was sampled, taken at random inside each plot, after the plants reached the R8 stage. }\end{array}$ \\
\hline 7 & NGP & unit & $\begin{array}{l}\text { It was carried out based on the ratio of the number of grains per plant in each plot to the number of } \\
\text { pods. }\end{array}$ \\
\hline 8 & GY & $\mathrm{kg} \mathrm{ha}^{-1}$ & $\begin{array}{l}\text { It was obtained from mechanized harvesting and weighing of the grains from the useful area of each } \\
\text { experimental plot automatically with an experimental harvester from the brand Almaco SPC- } 40 \text {. After } \\
\text { harvest, the results were corrected for humidity of } 13 \% \text {. }\end{array}$ \\
\hline
\end{tabular}

The estimate of maximum technical efficiency (MET) was obtained by to equation the follow: MET $=-[(b 1) /(2 b 2)])$. The quadratic regression equation was adjusted. The software used in all analyzes was the Statistical Analysis System (SAS 2013).

\section{RESULTS AND DISCUSSION}

According to the Figure 1, the meteorological conditions that occurred in Experiment 2 are characteristic of the rain regime called "El Niño". The pluviometric indexes were the highest recorded for the region of Arapongas-PR. In this sense, it can be said that these conditions contrast with the conditions of Experiment 1, where there was a seasonality of rainfall distribution, mainly during the grain filling period. The temperature conditions in the 2015/2016 harvest were within ideal levels for soybean culture, which contrasts with the temperatures recorded in experiment 1 , which revealed temperatures above $30^{\circ} \mathrm{C}$ during most of the grain filling period.

In general, the 1st experiment showed periods with maximum temperatures above $30^{\circ} \mathrm{C}$ in most of the plant development and absence of rain during grain filling, which promoted strong impacts on the soy granulation. The 2nd experiment was carried out under the meteorological conditions characteristic of the rain regime called "El Niño", where the rainfall indexes were the highest ever recorded for the region of Arapongas-PR.

The results of measurement of the plant lodging variable were not analyzed statistically, due to the nonoccurrence of bedded plots in both agricultural crops.

Analysis of variance - ANOVA. The results of the analysis of variance (ANOVA) for the variables plant height $(\mathrm{PH})$, height of insertion of the first pod (HIP), leaf area index (LAI), normalized difference vegetation index (NDVI), grain yield (GY), number of pods per plant (NPP) and number of grains per pod (NGP) are described in Table 2. ANOVA revealed significant effects for the triple expxarrangementxpop interaction for the variable LAI, NDVI, GY, NPP and NGP. It revealed significance for the double interactions expxpop, expxarrangement and pop $\times$ arrangement in the variable HIP.

Table 2. Summary of analysis of variance (ANOVA) for the characteristics of height of insertion of the first pod (HIP), plant height (PH), leaf area index (LAI), normalized difference vegetation index (NDVI), grains yield (GY), number of pods per plant (NPP) and number of grains per pod (NGP) evaluated in the 2013/2014 and 15/16 harvests.

\begin{tabular}{|c|c|c|c|c|c|c|c|c|}
\hline \multirow{2}{*}{ Variation source } & \multirow{2}{*}{$\mathrm{GL}$} & \multicolumn{7}{|c|}{ Mean square } \\
\hline & & AIV & ALP & LAI & NDVI & GY & NVP & NGP \\
\hline Block/Exp & 6 & $7.5^{\mathrm{ns}}$ & $36^{\text {ns }}$ & 3.26 & 19.27 & 257639.4 & $47.34^{\mathrm{ns}}$ & $0.08^{\text {ns }}$ \\
\hline Exp & 1 & $3803.8^{\text {ns }}$ & $38272.4^{* *}$ & $21.67^{*}$ & $2.00^{\mathrm{ns}}$ & $79882183.4^{* *}$ & $724.9^{*}$ & $9.3^{* *}$ \\
\hline Population & 5 & $196.6^{* *}$ & $537^{* *}$ & $33.39^{* *}$ & $125.19^{* *}$ & $1069870^{* *}$ & $15387.4^{* *}$ & $0.36^{*}$ \\
\hline Arrangement $(\mathrm{A})$ & 2 & $31.4^{\pi x}$ & $91.4^{*}$ & $3.41^{*}$ & $9.63^{\mathrm{ns}}$ & $5635461.1^{\pi \times}$ & $233.8^{\text {ns }}$ & $0.03^{\text {ns }}$ \\
\hline Exp*Pop & 5 & $58.7^{* *}$ & $30.6^{\text {ns }}$ & $5.72^{*}$ & $16.59^{*}$ & $1387982.9^{* *}$ & $2830.0^{* *}$ & $1.26^{* *}$ \\
\hline $\operatorname{Exp}{ }^{*} A$ & 2 & $14.8^{\pi \times}$ & $3.4^{\mathrm{ns}}$ & $1.58^{\mathrm{ns}}$ & $42.84^{\pi}$ & $4948015.9^{\pi x}$ & $454.7^{\star}$ & $0.01^{\mathrm{ns}}$ \\
\hline Pop*A & 10 & $19.6^{* *}$ & $24.1^{\mathrm{ns}}$ & $2.00^{\mathrm{ns}}$ & $2.10^{\mathrm{ns}}$ & $735115.2^{* *}$ & $137.1^{\mathrm{ns}}$ & $0.05^{\mathrm{ns}}$ \\
\hline Exp*Pop*A & 10 & $13.5^{\mathrm{ns}}$ & $18.0^{\text {ns }}$ & $2.77^{*}$ & $13.39^{*}$ & $815481.6^{* *}$ & $278.91^{*}$ & $0.32^{*}$ \\
\hline Error & 102 & 7.4 & 20.4 & 1.26 & 6.31 & 314664.5 & 80.5 & 0.09 \\
\hline Mean & & 14.2 & 77.8 & 4.15 & 82.70 & 3348.2 & 46.73 & 2.07 \\
\hline CV\% & & 19.1 & 5.8 & 27.09 & 3.04 & 16.8 & 19.19 & 15.05 \\
\hline
\end{tabular}

*Significant for the $\mathrm{F}$ test at $5 \%$ probability.

${ }^{n s}$ not significant, ${ }^{*}$ and ${ }^{* *}$ significant at the level of $5 \%$ and $1 \%$, respectively, by the $\mathrm{F}$ test. 
The variable HIP showed significance of pop xarrangement, indicating that depending on the arrangement of plants a specific population that may have a better performance. Barni et al. (1995), Gaudêncio et al. (1990) and Peixoto et al. (2000) reported that soy tolerates a wide variation in the plant population, where greater changes are observed in morphology than in grain yield. The results showed that the 2013/2014 crop had a higher HIP compared to the 2015/2016 crop for all populations studied (Table 3).

Table 3. Split between the interaction between the population $\times 2013 / 14$ harvest and 2015/16 harvest, population $\times$ arrangement and arrangement $\times$ cultivation of crop for the variable height of insertion of the first pod (HIP).

\begin{tabular}{|c|c|c|}
\hline Population $^{\#}$ & Harvest $2013 / 14$ & Harvest 2015/16 \\
\hline 100,000 & $13.1 \mathrm{~A}$ & $7.08 \mathrm{~B}$ \\
\hline 200,000 & $15.29 \mathrm{~A}$ & $7.67 \mathrm{~B}$ \\
\hline 300,000 & $17.21 \mathrm{~A}$ & $9.08 \mathrm{~B}$ \\
\hline 400,000 & $22.59 \mathrm{~A}$ & $9.92 \mathrm{~B}$ \\
\hline 500,000 & $23.97 \mathrm{~A}$ & $9.67 \mathrm{~B}$ \\
\hline 600,000 & $23.03 \mathrm{~A}$ & $10.92 \mathrm{~B}$ \\
\hline Ponulation & \multicolumn{2}{|c|}{ Row arrangement } \\
\hline ropulation & 0.25 & $0.25 \times 0.50$ \\
\hline $100,000^{*}$ & $9.6^{\mathrm{a}}$ & $11.02^{a}$ \\
\hline 200,000 & $11.35^{\mathrm{a}}$ & $11.65^{\mathrm{a}}$ \\
\hline 300,000 & $12.00 \mathrm{~A}$ & $13.16^{\mathrm{a}}$ \\
\hline 400,000 & 15.11B & $15.53 \mathrm{AB}$ \\
\hline 500,000 & $17.71^{\mathrm{a}}$ & $16.80^{\mathrm{a}}$ \\
\hline 600,000 & $13.82 \mathrm{C}$ & 16.68B \\
\hline Arrangements & \multicolumn{2}{|l|}{ Harvest $2013 / 2014$} \\
\hline $0.25^{\star \star}$ & $17.78 \mathrm{Ba}$ & $8.75 \mathrm{aB}$ \\
\hline 0.50 & $19.89 a A$ & $9.25 \mathrm{aB}$ \\
\hline $0.25 \times 0.50$ & $20.32 \mathrm{aA}$ & $9.16 \mathrm{aB}$ \\
\hline
\end{tabular}

The results of the comparison of means of interaction between population $\times$ arrangement for variable HIP revealed that the populations of 100 to 300 thousand plants ha $^{-1}$ are statistically equal. For a population of 400 thousand plants ${ }^{-1}$ the largest HIP was in the 0.50 arrangement, not statistically differing from $0.25 \times 0.50$, the smallest HIP in this population was in the 0.25 arrangement. Considering the population of 600 thousand plants $^{-1}$ the highest HIP was in the $0.25 \times 0.50$ arrangement, with the lowest HIP in the $0.0 .25 \mathrm{~m}$ arrangement (Table 3).

In the analysis of the HIP response as a function of the different populations for each plant arrangement in the first growing season, there was a tendency to increase the HIP for the 0.25 and 0.50 arrangements up to the population of 500 thousand plants ha $^{-1}$, after there was a tendency to reduce HIP. In contrast, for the $0.25 \times 0.50$ arrangement, there is a tendency to increase the HIP from 500 to 600 thousand plants ha ${ }^{-1}$. Regarding the 2 nd cultivation season, there was a linear trend of increasing HIP with an increase in the plant population, however the means were considerably lower than the 1st cultivation season (Figure 2).

The lowest HIP values were observed in the 2015/16 crop in the spacing where the plants were distributed equidistant, provided by the smallest populations with means values of the order of $7.5 \mathrm{~cm}$. The results obtained in the 2013/14 harvest, the lowest values were in the order of $14 \mathrm{~cm}$. The effect of the lower insertion heights of the first pod brings complications in the cultural treatments, as well as hinders the mechanical harvesting, which can cause significant losses in the field and even the inability to adopt the cultivar.

Some cultivars express these characteristics in a very peculiar way, for example, Gewehr et al. (2014) studied the behavior of five soybean varieties, BMX Turbo RR, BMX Força RR, BMX Potencia RR, BRS 246 RR and Fundacep $59 \mathrm{RR}$, and observed that, according to the population increase, the HIP also obtained the highest values, being that the Fundacep 59 variety had the highest HIP values. Studies in different rows spacing corroborated these results, and the increase in the population of plants in cross-sowing or in conventional sowing generally influences the plants height, thus reflecting in the HIP, with some varieties stabilizing their growth in a given population. This increase in plant height is directly linked to the shading that plants undergo in high populations, in which there is a competition for adjacent plants for light (Lima et al. 2012).

This characteristic could be inherent to the cultivar, where in some cases, plants with a high arrangement and populations can exhibit the behavior of raising the height of the first pod (Urben Filho and Souza 1993). In studies 
by Gewehr et al. (2014) it was found that, regardless of the type of growth (determined or undetermined), the plants showed interaction between the population and the rows spacing for the HIP, with higher means in larger populations. The higher HIP values can be considered an important characteristic, because the higher the HIP, the smaller the loss of grains in the harvest, since the higher HIP facilitates the entry of the harvester cutter bar from the harvesters, thus avoiding the loss in the harvest. According to Heiffig et al. (2006), the height of insertion of the first pod must be from 0.10 to $0.15 \mathrm{~m}$ to obtain a harvest with a minimum of losses by the cutter bar. Thus, the means observed in the two sowing systems meet the ideal heights reported by the author. Chioderoli et al. (2012) and Pereira Júnior et al. (2010) observed soybean AIV of 0.14 and $0.15 \mathrm{~m}$, respectively, and stated that these values are within the normal standards for cutting height in mechanized harvesting, in which they obtained lower losses during the harvesting process.
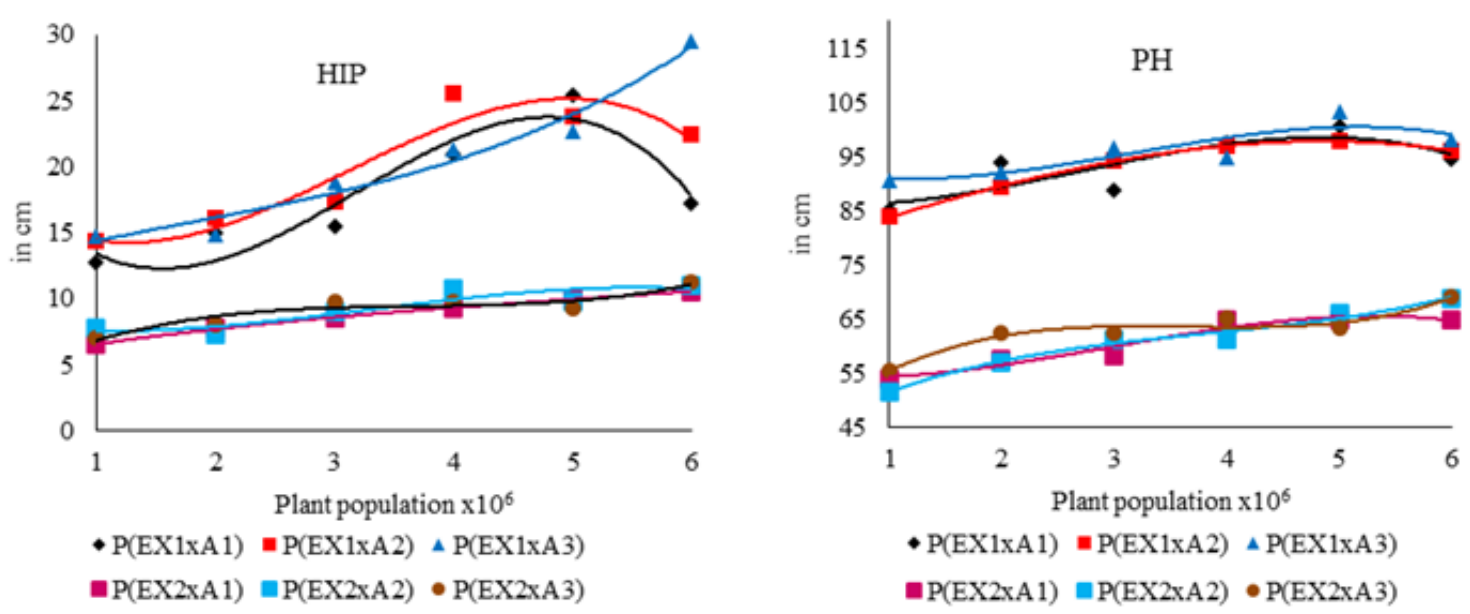

Figure 2. Effect of the interaction of plant population factors $\times$ between rows in the variable height of the first pod (HIP) in the 2013/2014 harvest: $y(E x p 1 A 1)=-0.67 x^{3}+6.43 x^{2}-15.10 x+22.72 R^{2}=0.88, y$ $(E x p 1 A 2)=-0.43 x^{3}+4.05 x^{2}-8.22 x+19.00 R^{2}=0.90, y(E x p 1 A 3)=0.08 x^{3}-0.47 x^{2}+2.63 x+12.09 R^{2}=$ 0.96 and for the $2015 / 16$ harvest: $y(E x p 2 A 1)=0.01 x^{3}-0.18 x^{2}+1.62 x+5.08 R^{2}=0.99, y(E x p 2 A 2)=-0$, $07 x^{3}+0.7619 x^{2}-1.41 x+8.25 R^{2}=0.81, y(E x p 2 A 3)=0.11 x^{3}-1.28 x^{2}+4.88 x+3.08 R^{2}=0.90$.

Regression equations for plant population interaction $\times$ row arrangement of the plant height variable $(\mathrm{PH})$ in the 2013/2014 harvest: $y(\operatorname{Exp1A1})=-0.31 \mathrm{x}^{3}+2.52 \mathrm{x}^{2}-2.45 \mathrm{x}+86.56 \mathrm{R}^{2}=0,68$, y $(\operatorname{Exp} 1 \mathrm{A2})=-$ $0.07 x^{3}-0.15 x^{2}+6.71 x+77.28 R^{2}=1, y(E x p 1 A 3)=-0.29 x^{3}+2.85 x^{2}-5.44 x+93.73 R^{2}=0.76$ and for 2015/16 harvest: $y(E x p 2 A 1)=-0.22 x^{3}+1.98 x^{2}-2.25 x+54.75 R^{2}=0.93, y(E x p 2 A 2)=0.21 x^{3}-2.47 x^{2}+$ $11.52 x+42.25 R^{2}=0.98, y(E x p 2 A 3)=0.46 x^{3}-5.17 x^{2}+18.68 x+41.33 R^{2}=0.94$

In the analysis of the plant height $(\mathrm{PH})$ of the plant arrangement, there were significant differences, the plant arrangement $0.25 \times 0.50$ was higher and it differed statistically from the other plant arrangements for the character $\mathrm{PH}$. When comparing the means of the cultivation of crops, it can be seen that the 2013/2014 harvest was higher than the 2015/2016 harvest for $\mathrm{PH}$, a result similar to the HIP, it is worth noting that the differences between the means are greater than $33 \mathrm{~cm}$ in height (Table 4).

Table 4. Comparison of means of the variable plant height (PH) between the different row arrangements and cultivation of crops.

\begin{tabular}{|c|c|c|c|}
\hline Row arrangements & $\mathrm{PH}$ & Harvest & $\mathrm{PH}$ \\
\hline $0.25^{\#}$ & $76.98 \mathrm{~b}$ & $2013 / 2014^{\# \#}$ & $94.07 \mathrm{a}$ \\
\hline 0.50 & $76.97 \mathrm{~b}$ & $2015 / 2016$ & $61.47 \mathrm{~b}$ \\
\hline $0.25 \times 0.50$ & $79.36 \mathrm{a}$ & & \\
\hline
\end{tabular}

Regarding the $\mathrm{PH}$ response (Figure 2) due to the different populations studied, initially there was a tendency to increase $\mathrm{PH}$, up to the population of 500 thousand plants ha ${ }^{-1}$, after a slight tendency to reduce plant height for the 1st harvest of cultivation. In the 2nd crop season, the PH were considerably lower, the 0.25 arrangement showed the same trend as the 1st crop, whereas the other arrangements showed a slight response to increase the $\mathrm{PH}$ in populations above 500 thousand plants ha ${ }^{-1}$.

However, for both experiments, the plant height was higher in larger populations. The results corroborate with Mattioni et al. (2008), in which the authors worked with organic soybean cultivation with different populations and 
also observed that the plants height (Gewehr et al. 2014) studying the influence of the plant population on plant height, there was no difference between the means of PH for the different populations studied, but the variable height of insertion of the first pod shows an increasing trend as the population increases. In this study, the values observed for the $\mathrm{PH}$ variable did not respond to the variable in relation to the different rows spacings, nor in relation to the interactions rows spacing and different plant populations. However, in the tests performed in different spacing when used $0.20 \mathrm{~m}$, obtained the highest plant height in the evaluation of 45 days after emergence.

Interaction in an experiment $\times$ arrangement $\times$ plant population. The significance for the triple interaction between experiment $\times$ arrangement $\times$ plant population indicates that the dependence on arrangement, population and crop yield. Barni et al. (1995), Gaudêncio et al. (1990) and Peixoto et al. (2000) reported that soybean management, as an arrangement and management, directly influence yield components, such as number of pods per plant, number of grains per pod, grain mass and grain yield.

The breakdown of the LAl variable is shown in Table 5. Regarding the comparison of the arrangements within each population and year, there were no differences for the 1st year between the arrangements in the populations of 100,300 and 600 thousand plants ha ${ }^{-1}$. The 0.25 plant arrangement has the highest $\mathrm{LAl}$, considering the populations of 400 and 500 thousand plants ha ${ }^{-1}$.

Table 5. Decomposition of the triple interaction of the experiment factor to the variable leaf area index (LAI).

\begin{tabular}{|c|c|c|c|}
\hline \multirow{2}{*}{ Population } & \multirow{2}{*}{ Arrangement } & \multicolumn{2}{|c|}{ LAI } \\
\hline & & Exp 1 & Exp 2 \\
\hline \multirow{3}{*}{100,000} & $0.25 \mathrm{~m}$ & $2.07 a A$ & $2.32 \mathrm{aA}$ \\
\hline & $0.5 \mathrm{~m}$ & $1.85 \mathrm{aA}$ & $2.10 \mathrm{aA}$ \\
\hline & $0.25 \times 0.50 \mathrm{~m}$ & $1.90 \mathrm{aA}$ & $2.48 \mathrm{aA}$ \\
\hline \multirow{3}{*}{200,000} & $0.25 \mathrm{~m}$ & 2.80abA & $3.87 a A$ \\
\hline & $0.5 \mathrm{~m}$ & $4.02 \mathrm{aA}$ & $4.50 \mathrm{aA}$ \\
\hline & $0.25 \times 0.50 \mathrm{~m}$ & $2.27 \mathrm{bB}$ & $3.97 a A$ \\
\hline \multirow{3}{*}{300,000} & $0.25 \mathrm{~m}$ & $4.57 a \mathrm{~A}$ & $4.87 a \mathrm{~A}$ \\
\hline & $0.5 \mathrm{~m}$ & 3.87aA & $4.70 \mathrm{aA}$ \\
\hline & $0.25 \times 0.50 \mathrm{~m}$ & 4.62aA & $4.45 a \mathrm{~A}$ \\
\hline \multirow{3}{*}{400,000} & $0.25 \mathrm{~m}$ & $5.80 \mathrm{aA}$ & $5.65 a A$ \\
\hline & $0.5 \mathrm{~m}$ & $3.75 \mathrm{bA}$ & $4.07 \mathrm{bA}$ \\
\hline & $0.25 \times 0.50 \mathrm{~m}$ & 4.47abA & $3.60 \mathrm{bA}$ \\
\hline \multirow{3}{*}{500,000} & $0.25 \mathrm{~m}$ & $5.95 a A$ & $4.47 \mathrm{bB}$ \\
\hline & $0.5 \mathrm{~m}$ & $3.25 \mathrm{bB}$ & $6.00 \mathrm{aA}$ \\
\hline & $0.25 \times 0.50 \mathrm{~m}$ & $3.95 \mathrm{bA}$ & 5.12abA \\
\hline \multirow{3}{*}{600,000} & $0.25 \mathrm{~m}$ & $4.60 \mathrm{aB}$ & 7.07abA \\
\hline & $0.5 \mathrm{~m}$ & $4.57 \mathrm{aA}$ & $5.72 \mathrm{bA}$ \\
\hline & $0.25 \times 0.50 \mathrm{~m}$ & 3.87aB & $8.0 \mathrm{aA}$ \\
\hline
\end{tabular}

For the 2nd experiment, the differences occurred only between the arrangements for populations above 300 thousand plants $\mathrm{ha}^{-1}$. The 0.25 arrangement is superior in the population of 400 thousand plants ha ${ }^{-1}$ in 500 thousand plants $\mathrm{ha}^{-1}$ the arrangement 0.5 is superior and in the population of 600 thousand plants ha ${ }^{-1}$ the arrangement of paired-rows $0,25 \times 0.5$ has a higher LAI.

When comparing the 1st and 2nd harvests in the $0.25 \times 0.50$ arrangement and the population of 200 thousand plants $\mathrm{ha}^{-1}$ the 2 nd year revealed a higher LAI, in the same sense for 500 thousand plants ha ${ }^{-1}$ for $0.5 \mathrm{~m}$ arrangement and 600 thousand plants ha ${ }^{-1}$ for 0.25 and $0.25 \times 0.5$ arrangements. The 1 st crop showed the highest LAl in the population of 500 thousand plants $\mathrm{ha}^{-1}$ in the $0.25 \mathrm{~m}$ arrangement.

Regarding the response of the variable leaf area index, in the first harvest (Figure 3) the populations of 400 and 500 thousand plants showed a maximum in the 0.25 and $0.25 \times 0.50$ arrangements, after showing a tendency to reduce the LAl, and in the 0.50 arrangement showed a tendency to increase the LAl from the population of 500 thousand plants. The results of the $2015 / 16$ crop show a response contrary to the 1 st crop, where the 0.25 and $0.25 \times 0.50$ arrangements tended to increase the LAI from 500 thousand plants, whereas the 0.50 arrangement showed a tendency to reduce the LAl after this same population.

Regarding the dismemberment of the triple interaction for variable NDVI, there were significant differences for the 1st and 2nd harvest in the population of 100 thousand plants, where the largest NDVI was for the $0.25 \mathrm{~m}$ arrangement, compared with 0.5 in the 1 st harvest. In contrast, in the 2nd harvest, this same arrangement had a lower NDVI. In the 2nd harvest, there were significant differences for the population of 400 thousand plants with superiority for the 0.25 arrangements and paired-rows in relation to 0.50 meters (Table 6). 

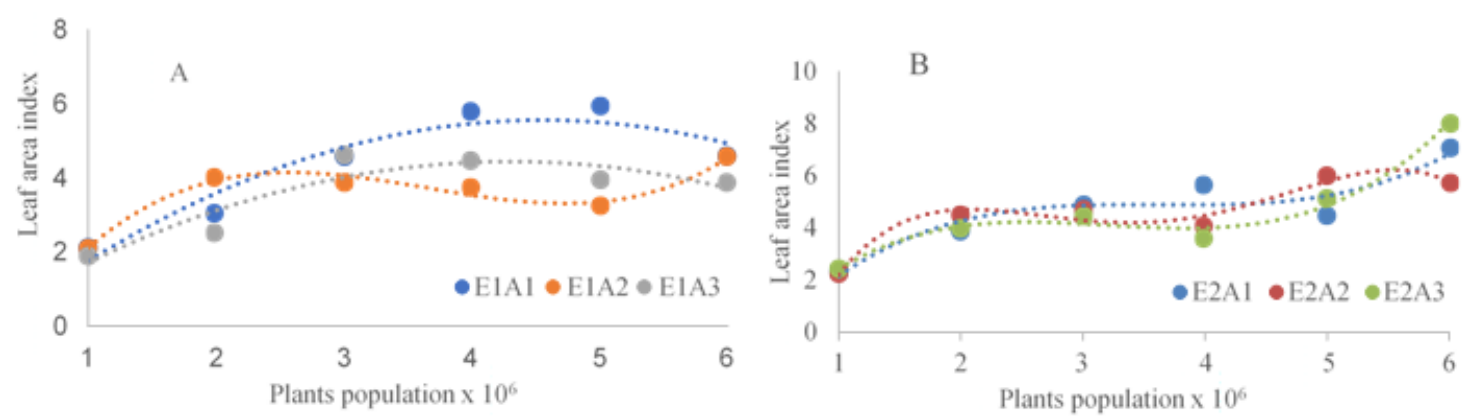

Figure 3. Effect of the interaction of plant arrangements, populations and 2013/2014 crop (E1) E1A1: y $=-0.30 x^{2}+2.74 x-0.69 R^{2}=0.91$, E1A2: $y=0.16 x^{3}-1.85 x^{2}+6.20 x-2.4 R^{2}=0.97$, E1A3: $y=-0.25 x^{2}+2.1 x-$ $0.17 R^{2}=0.84$ and $2015 / 2016$ (E2) E2A1: $y=0.15 x^{3}-1.66 x^{2}+6.01 x-2.33 R^{2}=0.89$, E2A2: $y=-0.12 x^{4}+$ $1.82 x^{3}-9.31 x^{2}+19.51 x-9.68 R^{2}=0.95$, E2A3: $y=0.21 x^{3}-2.06 x^{2}+6.33 x-2.06 R^{2}=0.98$ for the variable leaf area index (LAI).

Table 6. Decomposition of the triple interaction and comparison of means for the NDVI variable.

\begin{tabular}{cccc}
\hline \multirow{2}{*}{ Population } & \multirow{2}{*}{ Arrangement } & \multicolumn{2}{c}{ NDVI } \\
\cline { 3 - 4 } & & Exp 1 & Exp 2 \\
& $0.25 \mathrm{~m}$ & $80.75 \mathrm{aA}$ & $86.50 \mathrm{bB}$ \\
\multirow{2}{*}{100,000} & $0.5 \mathrm{~m}$ & $73.50 \mathrm{bB}$ & $81.75 \mathrm{aA}$ \\
& $0.25 \times 0.50 \mathrm{~m}$ & $76.75 \mathrm{abB}$ & $81.00 \mathrm{aA}$ \\
\multirow{2}{*}{200,000} & $0.25 \mathrm{~m}$ & $84.25 \mathrm{aA}$ & $83.25 \mathrm{aA}$ \\
& $0.5 \mathrm{~m}$ & $81.25 \mathrm{aA}$ & $82.25 \mathrm{aA}$ \\
\hline \multirow{2}{*}{300,000} & $0.25 \times 0.50 \mathrm{~m}$ & $81.00 \mathrm{aA}$ & $83.25 \mathrm{aA}$ \\
& $0.25 \mathrm{~m}$ & $84.75 \mathrm{aA}$ & $82.75 \mathrm{aA}$ \\
& $0.5 \mathrm{~m}$ & $83.25 \mathrm{aA}$ & $83.75 \mathrm{aA}$ \\
\hline \multirow{2}{*}{400,000} & $0.25 \times 0.50 \mathrm{~m}$ & $83.25 \mathrm{aA}$ & $83.00 \mathrm{abA}$ \\
& $0.25 \mathrm{~m}$ & $84.75 \mathrm{aA}$ & $79.75 \mathrm{bB}$ \\
& $0.5 \mathrm{~m}$ & $84.00 \mathrm{aA}$ & $83.50 \mathrm{aA}$ \\
\hline \multirow{2}{*}{500,000} & $0.25 \times 0.50 \mathrm{~m}$ & $84.50 \mathrm{aA}$ & $83.50 \mathrm{aA}$ \\
& $0.25 \mathrm{~m}$ & $85.25 \mathrm{aA}$ & $84.00 \mathrm{aA}$ \\
& $0.5 \mathrm{~m}$ & $84.25 \mathrm{aA}$ & $84.25 \mathrm{aA}$ \\
\hline \multirow{2}{*}{600,000} & $0.25 \times 0.50 \mathrm{~m}$ & $84.50 \mathrm{aA}$ & $84.00 \mathrm{aA}$ \\
& $0.25 \mathrm{~m}$ & $86.00 \mathrm{aA}$ & $84.50 \mathrm{aA}$ \\
error. & $0.5 \mathrm{~m}$ & $84.25 \mathrm{aA}$ & $84.50 \mathrm{aA}$ \\
\hline
\end{tabular}

When comparing the NDVI variable in the different harvests, the 1st crop had the highest NDVI in the population of 100 thousand for arrangement 0.25 , whereas for the other arrangements, the 2nd crop had the highest NDVI. Another significance revealed was for the population of 400 thousand plants, where in the 0.50 arrangement, the 1st crop was greater than the 2nd crop.

For the regression equations in the 1st harvest, NDVI had an increasing behavior up to the populations of 500 thousand plants in the three studied plant arrangements. In the analysis of the 2nd harvest, the 0.50 arrangements and paired-rows revealed a positive linear behavior, as the plant population increases, reaching a maximum in the population of 500 thousand plants. In contrast, in the 0.25 arrangement, there was a quadratic response, initially increasing, tending to reduce the population of 600 thousand plants (Figure 4).

As a way of demonstrating the relationship between the LAI and the NDVI, it is shown in Figure 5 that the higher the LAl, the greater the NDVI tends to be for both cultivation of crops. This demonstrates the linear and positive relationship between LAI and NDVI.

The results of the Split of the means of the triple population $x$ arrangement $x$ cultivation of crop for the variables grain yield (GY), number of pods per plant (NPP) and number of grains per pod (NGP) are shown in Table 7.

With regard to the deployment of the GY triple interaction, there is a superiority of the means of the second crop, compared to the means of the first crop, for all studied populations and plant arrangements. The results obtained for this source of variation are possibly related to the precipitation data, which are shown in Figure 1, where low levels of precipitation are recorded in the first crop, and higher and higher levels in the second crop. Precipitation among all meteorological elements is crucial for obtaining greater grain yield, as water is directly associated with the growth and development phases of the plant, as well as with the development of reproductive 
structures and with the filling of grains. So, the stress due to water deficiency in any of these stages is likely to compromise the grain yield components and grain yield, specifically.
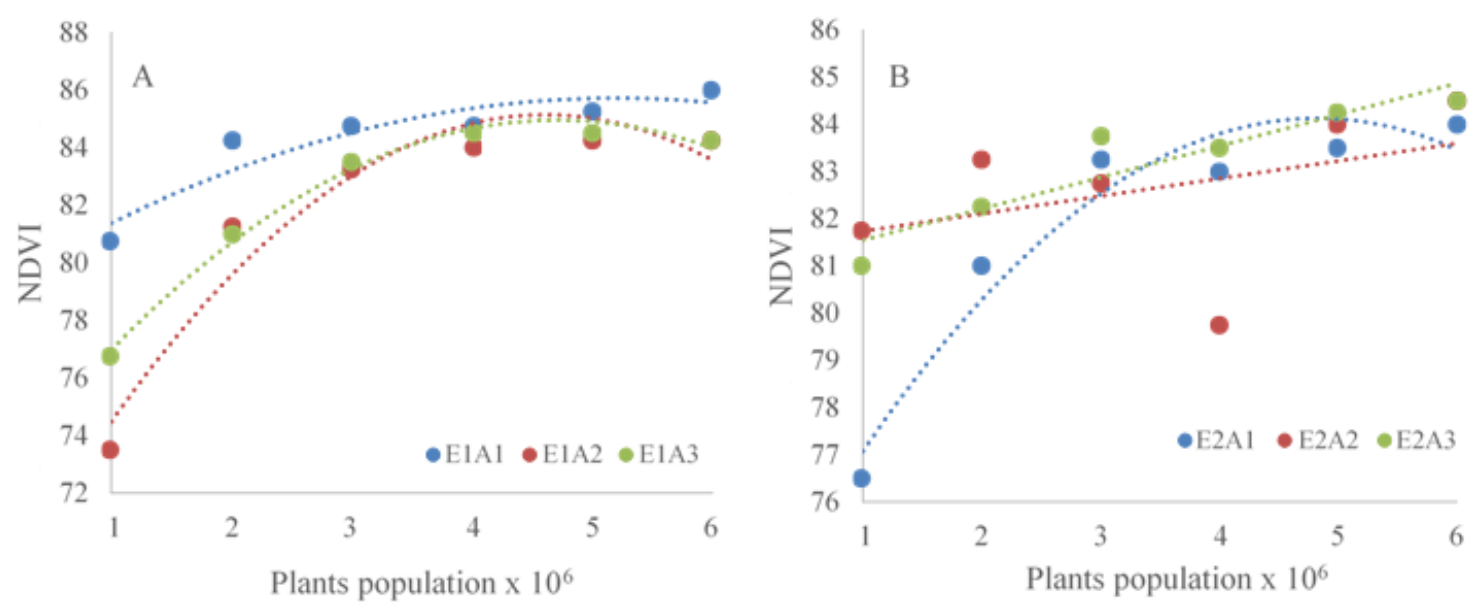

Figure 4. Effect of the interaction of plant, population and 2013/2014 crop arrangements (E1) E1A1: $y=$ $0.83 x+81.36 R^{2}=0.72, E 1 A 2: y=-0.817 x 2+7.53 x+67.77 R^{2}=0.93, E 1 A 3: y=-0.58 x 2+5.46 x+72.1 R^{2}$ $=0.99$ and 2015/2016 (E2) E2A1: $y=-0.48 x 2+4.65 x+72.9 R^{2}=0.93$, E2A2: $y=81.36$, E2A3: $y=0.66 x+$ $80.88 R^{2}=0.86$ for the NDVI variable.
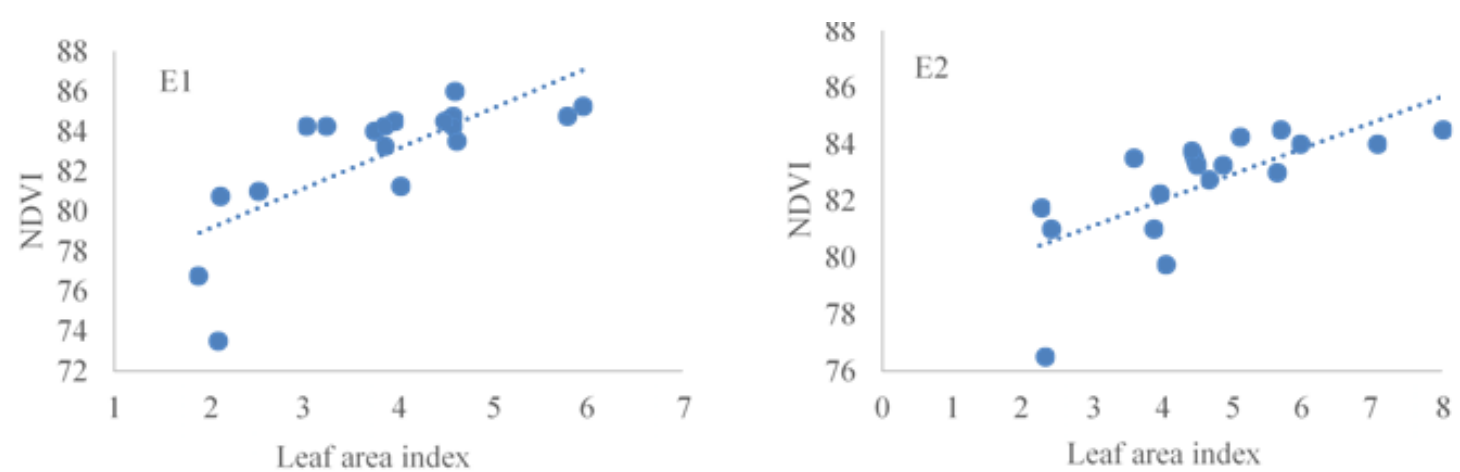

Figure 5. Relationship between the LAI $x$ NDVI for the 1st crop of E1 crop: $y=2.01 x+75.10 R^{2}=0.54$ and the 2 nd cultivation of $\operatorname{crop}(E 2): y=0.91 x+78.37 R^{2}=0.48$.

Table 7. Decomposition of the triple interaction of the Nested experiment with the double interaction Population $x$ Arrangement for the GY grain yield variables; mass of a thousand grains MTG; number of grains per NGP plant; number of pods per NPP plant.

\begin{tabular}{|c|c|c|c|c|c|c|c|}
\hline \multirow{2}{*}{ Population } & \multirow{2}{*}{ Arrangement } & \multicolumn{2}{|c|}{ GY } & \multicolumn{2}{|c|}{ NVP } & \multicolumn{2}{|c|}{ NGV } \\
\hline & & $\operatorname{Exp} 1$ & Exp 2 & Exp 1 & Exp 2 & Exp 1 & Exp 2 \\
\hline & $0.25 \mathrm{~m}$ & $2501 \mathrm{aB}$ & $3858 \mathrm{bA}$ & $140 \mathrm{aB}$ & $62 \mathrm{bA}$ & $1.65 \mathrm{bB}$ & $2.75 \mathrm{aA}$ \\
\hline \multirow[t]{3}{*}{100,000} & $0.5 \mathrm{~m}$ & 2337 a B & $3663 \mathrm{bA}$ & $121 \mathrm{bB}$ & $77 \mathrm{aA}$ & $2.12 \mathrm{aB}$ & $2.37 \mathrm{abA}$ \\
\hline & $0.25 \times 0.50 \mathrm{~m}$ & $2558 \mathrm{aB}$ & $5060 \mathrm{aA}$ & $94 \mathrm{cB}$ & $73 a b A$ & $2.45 \mathrm{aB}$ & $2.05 \mathrm{bA}$ \\
\hline & $0.25 \mathrm{~m}$ & $2526 \mathrm{aB}$ & $3534 \mathrm{bA}$ & $61 \mathrm{a} B$ & $55 \mathrm{aA}$ & $2.25 \mathrm{aB}$ & $1.82 \mathrm{aA}$ \\
\hline \multirow[t]{3}{*}{200,000} & $0.5 \mathrm{~m}$ & $2487 \mathrm{aB}$ & $3244 \mathrm{bA}$ & $57 \mathrm{aB}$ & $48 \mathrm{aA}$ & $2.15 \mathrm{aB}$ & $1.92 \mathrm{aA}$ \\
\hline & $0.25 \times 0.50 \mathrm{~m}$ & $2456 \mathrm{aB}$ & $4483 \mathrm{aA}$ & $56 \mathrm{aB}$ & $56 \mathrm{aA}$ & $2.30 \mathrm{aB}$ & $2.07 \mathrm{aA}$ \\
\hline & $0.25 \mathrm{~m}$ & $2633 \mathrm{aB}$ & $3684 \mathrm{bA}$ & 36 a B & $41 \mathrm{aA}$ & $2.52 \mathrm{aB}$ & $1.77 \mathrm{aA}$ \\
\hline \multirow[t]{3}{*}{300,000} & $0.5 \mathrm{~m}$ & $2623 \mathrm{aB}$ & $4167 \mathrm{bA}$ & $36 \mathrm{aB}$ & $44 \mathrm{aA}$ & $2.60 \mathrm{aB}$ & $1.75 \mathrm{aA}$ \\
\hline & $0.25 \times 0.50 \mathrm{~m}$ & $2700 \mathrm{aB}$ & $5604 \mathrm{aA}$ & $35 \mathrm{aB}$ & $37 \mathrm{aA}$ & $2.47 \mathrm{aB}$ & $2.05 \mathrm{aA}$ \\
\hline & $0.25 \mathrm{~m}$ & $2916 \mathrm{aB}$ & $4452 \mathrm{abA}$ & $38 \mathrm{aB}$ & 38 a $A$ & $2.32 \mathrm{aB}$ & $1.50 \mathrm{aA}$ \\
\hline \multirow[t]{3}{*}{400,000} & $0.5 \mathrm{~m}$ & $2364 \mathrm{aB}$ & $3639 \mathrm{bA}$ & $28 \mathrm{aB}$ & $37 \mathrm{aA}$ & $2.50 \mathrm{aB}$ & $1.57 \mathrm{aA}$ \\
\hline & $0.25 \times 0.50 \mathrm{~m}$ & $2700 \mathrm{aB}$ & 5316 aA & $27 \mathrm{aB}$ & $37 \mathrm{aA}$ & $2.35 \mathrm{aB}$ & $1.57 \mathrm{aA}$ \\
\hline & $0.25 \mathrm{~m}$ & $2838 \mathrm{aB}$ & $3357 \mathrm{bA}$ & $28 \mathrm{aB}$ & 33 a $A$ & $2.57 \mathrm{abB}$ & $1.42 \mathrm{aA}$ \\
\hline \multirow[t]{3}{*}{500,000} & $0.5 \mathrm{~m}$ & $2403 \mathrm{aB}$ & $4310 \mathrm{aA}$ & $27 \mathrm{aB}$ & $31 \mathrm{aA}$ & 2.17 bB & $1.72 \mathrm{aA}$ \\
\hline & $0.25 \times 0.50 \mathrm{~m}$ & $2718 \mathrm{aB}$ & $4059 \mathrm{abA}$ & $25 \mathrm{aB}$ & 36 aA & $2.62 \mathrm{aB}$ & $1.60 \mathrm{aA}$ \\
\hline & $0.25 \mathrm{~m}$ & $2871 \mathrm{aB}$ & 2879 b A & $22 \mathrm{aB}$ & $33 \mathrm{aA}$ & $2.50 \mathrm{aB}$ & 1.60 a A \\
\hline \multirow[t]{2}{*}{600,000} & $0.5 \mathrm{~m}$ & $2449 a B$ & $3881 \mathrm{aA}$ & $24 \mathrm{aB}$ & $31 \mathrm{aA}$ & $2.22 \mathrm{abB}$ & $1.50 \mathrm{aA}$ \\
\hline & $0.25 \times 0.50 \mathrm{~m}$ & $2780 \mathrm{aB}$ & $3869 \mathrm{aA}$ & $26 \mathrm{aB}$ & $32 \mathrm{aA}$ & 2.07 bB & $1.62 \mathrm{aA}$ \\
\hline
\end{tabular}

* Means followed by uppercase letters in the line and lowercase letters in the column do not differ statistically at $5 \%$ probability of error. 
In the analysis of the comparison of means of experiment 1, for the same population, we noticed the absence of significant effects for comparing arrangements in the same population in all experiment 1 (Table 7). It is noteworthy that the mean productivity of all sources of variation was below 3 tons, that is to say close to the national mean, a characteristic that is not commonly observed in tests conducted in the region, in which the responses to grain yield are considerably higher.

The presence of water stress in the 2013/2014 harvest (Figure 1) reveals that the effects were considerably pronounceable, which neutralized the expression of significance of the other sources of variation present in the experiment (population and plant arrangement). Biologically, stress is considered a significant deviation from the ideal conditions in which plants are grown, preventing them from fully expressing their genetic potential for growth, development and reproduction, the changes and responses induced, at all functional levels of the organism, at first, they are reversible (elastic deformation), but can become permanent (plastic deformation). Abiotic stresses can trigger a series of responses in plants from changes in gene expression and cellular metabolism. The duration, severity and frequency, with which a stress is imposed, as well as the affected organs and tissues, stage of development and the genotype, also influence the response of plants to stress. Consequently, a different combination of conditions can cause different responses of plants to the same type of stress. The definition of drought is given as a multidimensional phenomenon, including not only water deficiency in the soil, but also that of the atmosphere, which, in turn, is fundamentally determined by relative humidity and air temperature.

The occurrence of abiotic stress, as mentioned above, compromises all the physiological mechanisms of growth and development of any crop, as plants under water stress conditions demand a greater amount of water to cool internal mechanisms, due to the greater stomatal opening, which can be highlighted here that water stress is generally associated with high temperatures, as well as increasing losses due to the reduction of transpiration, since species with $\mathrm{C}_{3}$, mechanisms, such as soybeans, are less efficient in the use of carbon molecules captured during photosynthesis.

Plants tend to adapt to water deficit conditions, but this is a very complex mechanism, involving morphological, physiological, biochemical and molecular changes. The leaf area and stomatal conductance (degree of stoma opening) are the main factors that determine transpiratory rates and, therefore, their decrease allows the water potential to increase or remain within limits that allow the maintenance of plant development. These factors are also the main determinants of carbon accumulated by plants. A reduced leaf area can lead to less interception of light radiation, thus contributing to the reduction of photosynthetic rates. The reduction in stomatal conductance leads to less $\mathrm{CO}_{2}$ inflow into the chloroplasts, causing reductions in photosynthetic rates and contributing to less biomass accumulation by the plant. Thus, stomatal conductance is the main aggravating factor of the photosynthetic process in conditions of water deficiency, another aggravating factor is the reduction of perspiration, which provides an increase in leaf temperature (with possible reflexes in the increase of maintenance respiration and photorespiration) by reducing stomatal conductance. Mechanisms that can overcome these problems are the development of cultivars with $\mathrm{CO}_{2}$, concentrating mechanisms, for example that found in $\mathrm{C}_{4}$. Another strategy would be to increase the specificity of the enzyme ribulose-1,5-bisphosphate carboxylase/oxygenase (rubisco) to $\mathrm{CO}_{2}$, thus reducing losses related to photorespiration in $\mathrm{C}_{3}$ plants. The increase in mesophilic conductance is directly associated with increases in photosynthetic rates, without the need for greater stomatal conductance. Another strategy involves increasing the specific leaf mass, since this increase represents a greater amount of photosynthetic machinery per unit leaf area (Taiz et al. 2017).

Regarding the second crop, significant differences are observed between the different plant arrangements for the same population. For the population of 100 thousand plants, the $0.25 \times 0.50 \mathrm{~m}$ arrangement has a mean GY higher than the 0.25 and $0.50 \mathrm{~m}$ arrangements, it is important to note that such superiority is above $1,200 \mathrm{~kg} \mathrm{ha}^{-1}$. In all studied populations, the $0.25 \times 0.50$ arrangement revealed means equal to or higher than the other arrangements in all studied plant populations.

In the analysis of the grain yield response by the regression analysis (Figure 6) considering the opening of the interaction of experiment 2 for the 0.25 and $0.25 \times 0.50$ arrangements, it demonstrated a high superiority of the $0.25 \times 0.50$ in the arrangement means in the populations of 300 and 400 thousand plants $\mathrm{ha}^{-1}$. The greater magnitude of means of the 0.25 arrangement is revealed in the population of 400 thousand plants ha ${ }^{-1}$. The

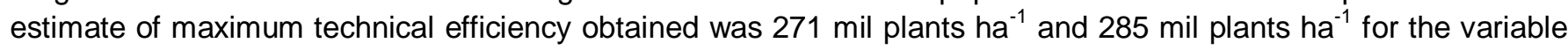
grain yield (Figure 6).

Peixoto et al. (2000) reported that the greatest response in grain yield is verified for the variation in the rows spacing of the plant, with a tendency for higher yields in the smallest spacing. The lower response of soy to the population is due to its ability to compensate for the use of space between plants. Pires et al. (2000), worked with the estimate of the soybean yield potential, considering two spacing of 20 and $40 \mathrm{~cm}$ and two plant populations 30 
and 40 plants $\mathrm{m}^{-2}$, concluded by the grain yield estimates that regardless of the number of plants the $20 \mathrm{~cm}$ spacing provides greater yield potential, especially at the beginning of grain filling, which leads to high yield if soil and weather conditions are favorable.
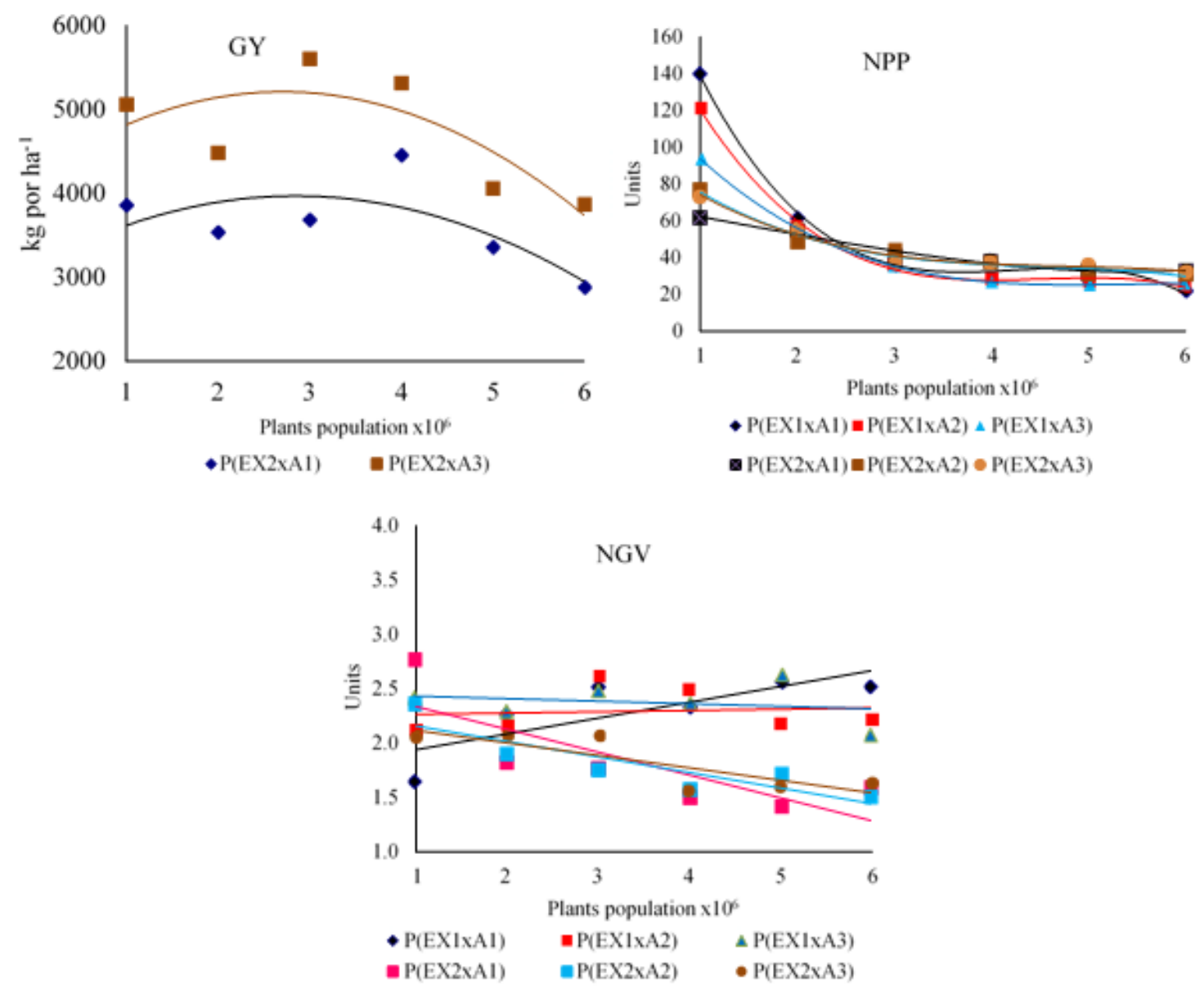

Figure 6. Decomposition of the triple interaction of the nested experiment factor with the double interaction Population $x$ Arrangement for the grain yield variables. y $\left(\right.$ Exp2A3) $=-135.27 x^{2}+732.08 x+4221.4 R^{2}=0.60, y$ $($ Exp2A1 $)=-102.63 x^{2}+585.28 x+3135.6 R^{2}=0.51$ and for the variable number of pods per plant. $y(E x p 1 A 1)=$ $-3.39 x^{3}+43.17 x^{2}-180 x+278.95 R^{2}=0.99, y(E x p 1 A 2)=-2.25 x^{3}+30.54 x^{2}-136.26 x+228.17 R^{2}=0.99, y$ $($ Exp1A3 $)=-0.82 x^{3}+13.52 x^{2}-72.53 x+153.5 R^{2}=1, y(E x p 2 A 1)=0.19 x^{3}-0.76 x^{2}-8.67 x+71.43 R^{2}=0.97, y$ $(\operatorname{Exp} 2 A 2)=-0.76 x^{3}+10.36 x^{2}-49.04 x+115.03 R^{2}=0.97, y(E x p 2 A 3)=-0.62 x^{3}+8.95 x^{2}-44.23 x+109.95 R^{2}=$ 0.97 and for the variable number of grains per pod (NGV) y $(\operatorname{Exp} 1 \mathrm{A1})=-0.0086 x+3.34 R^{2}=0.00, y(\operatorname{Exp} 1 \mathrm{A2})=$ $-0.2421 x+4.26 R^{2}=0.82, y(E x p 1 A 3)=0.68 x+0.18 R^{2}=0.97, y(E x p 2 A 1)=-0.044+1.74 R^{2}=0.10, y(E x p 2 A 2)$ $=0.021 x+1.53 R^{2}=0.12, y(E x p 2 A 3)=0.037 x+1.53 R^{2}=0.16$.

Regarding the variable number of pods per plant (NPP), experiment 1 had a higher NPP than experiment 2 (Table 7). Such differences were observed in the population of 100 thousand plants $\mathrm{ha}^{-1}$, the other treatments did not reveal significant effects. In the aforementioned population, for the first crop the arrangement with the highest NPP was 0.25 , in the second growing season it was 0.50 , but not different from the $0.25 \times 0.50$ arrangement. Ludwig et al. (2010) also evaluated the effect of the combination of different sowing densities and the types of habit, undetermined and determined growth on the reduction of the number of pods per plant and concluded that the largest populations had the lowest amount of pods per plant, data that corroborate with this job. The data in the present study are also in agreement with Peixoto et al. (2000), who describes that one of the components of the plant that contributes to the greater tolerance to variation in the population is the number of pods per plant that varies inversely with the increase or decrease in the plant population.

In the regression analysis for the NPP variable (Figure 6), populations between 300 and 600 thousand plants per hectare point to differences at very small levels. However, analyzing the results of the 0.50 arrangement for the two cultivation of crops in a more judicious way, we can thoroughly identify that with an increase in plant density in the row (population increase), which is greater in this arrangement, there is a sharper decline in the number of pods per plant. 
These responses, according to Pires et al. (2000) indicate that, for spacing, what controls the production or retention of vegetables is the competition between plants, since the increase in competition, by the density of plants in the row, decreases the number of vegetables. According to the author, this may reinforce the hypothesis of nutritional limitation exemplified by Heitholt et al. (1986). The author argues that in the initial stages of formation of the reproductive structures, $R_{2}$ e $R_{5}$, the reduction of the population did not allow to compensate for the number of vegetables $\mathrm{m}^{-2}$. After the start of filling, there is an increase in competition between plants for factors directly related to grain yield, reducing the individual productive capacity of plants under larger populations, tending to approach yields between populations.

The variable number of grains per pod is characterized as one of the most stable production components, among the others, however this study revealed through the data obtained the triple interaction for this variable. The decomposition of the triple interaction revealed that this variable suffered interaction only for experiment 1 and the arrangements with single-rows of $0.50 \mathrm{~m}$ and the paired $0.25 \times 0.50 \mathrm{~m}$. The NGP variable also showed differences between experiments 1 and 2 .

Experiment 1 showed a significant positive response for the different row spacing arrangements and for the interactions between the arrangements and the plant populations analyzed. The arrangement with double rows showed a lower number of grains per pod than the other spacing, however, experiment 2 was not able to demonstrate these responses for this variable. Procópio et al (2013) using the cross-planting system in soybean cultivar in a cultivar of indeterminate growth habit observed that this planting system showed a reduction in the number of grains per pod in the studied populations, but did not affect the final grain yield.

In the regression analysis for the variable NGP, the $0.25 \mathrm{~m}$ and paired-rows $0.25 \times 0.50 \mathrm{~m}$ arrangements of experiment 1 increased the NGP, as the plant population increased (Figure 6). The other interactions reduced NGP with an increase in plant population. However, the 0.25 and $0.50 \mathrm{~m}$ arrangements in experiment 2 revealed lower NGP, compared to the other interactions between experiment $x$ arrangement, for the respective growing season. Tourino et al. (2002) in their study with two spacing ( 0.45 and 0.60$)$ and five sowing densities $(10,13,16,19$, and 22 plants $\mathrm{m}^{-2}$ ) did not obtain differences for the number of grains per pod.

The results of the 2013/2014 harvest were significantly lower for grain yield and the main yield components of the 2015/2016 crop, however these results allow for a contrast of scenarios (water deficiency and excessive precipitation) for the analysis of plant arrangements and also for the populations used in the present work. It is interesting to note that the field results of a third crop, possibly will be directed towards the greater agronomic performance of arrangements with smaller spacing, as well as with the use of larger plant populations.

In conclusion, the performance of cultivar CA7442 RR1 revealed that the grain yield, number of pods per plant and number of grains per pod is dependent on the arrangement, plant population and agricultural crop. Under water stress conditions (2013/2014 harvest), there is no difference between the arrangements, but there is a tendency to reduce grain yield in larger populations. The grain yield obtained by cultivar CA7442 RR1, due to the interaction between year and the plants arrangement, showed superiority for the paired-rows in relation to the spacing with single-rows with $4,732 \mathrm{~kg} \mathrm{ha}^{-1}$ for the spacing $0.25 \times 0.50 \mathrm{~m}, 3,817 \mathrm{~kg} \mathrm{ha}^{-1}$ for the $0.50 \mathrm{~m}$ and 3,628 $\mathrm{kg} \mathrm{ha}^{-1}$ for the $0.25 \mathrm{~m}$, in the second year of cultivation, indicating a new proposal for rows spacing for the current models.

\section{Acknowledgements}

The authors would like to thank CNPq, CAPES, for financial assistance and scholarships.

\section{References}

Barni NA et al. 1985. Efeito da época de semeadura, espaçamento e população de plantas sobre o desempenho da soja [Glicyne max (L.) Merrill], em solo hidromórfico. Agronomia Sulriograndense 21:245-296.

Board JE et al. 1992. Temporal importance of greater light interception to increased yield in narrow-row soybean. Agronomy Journal 84:575579.

Bruin JL and Pedersen P. 2008. Effect of row spacing and seeding rate on soybean yield. Agronomy Journal 100:704-710.

Bruns HA. 2011. Comparisons of single-row and twin-row soybean production in the Mid-South. Agronomic Journal 103:703-708.

Conab - Companhia Nacional de Abastecimento. 2020. Acompanhamento da safra brasileira. Grãos. 1ํ Levantamento safra $2020 / 2021$.

Outubro de 2020. https://www.conab.gov.br/info-agro/safras/graos/boletim-da-safra-de-graos.

Cox WJ et al. 2010. Soybeans compensate at low seeding rate but not at high thinning rates. Agronomy Journal 102:1238-1243.

Cox WJ and Cherney JH. 2011. Growth and yield responses of soybean to row spacing and seeding rate. Agronomy Journal 103:123-128.

Chioderoli CA et al. 2012. Consórcio de Urochloas com milho em sistema plantio direto. Ciência Rural 42:1804-1810.

Crusciol CAC. 2013. Upland rice growth and mineral nutrition as affected by cultivars and sulfur availability. Soil Science Society of America Journal 77:328-335.

Duarte TC. 2016. Arranjos espaciais e doses de adubação na produtividade da cultura da soja e seus componentes. Revista Brasileira Engenharia Agrícola Ambiental 20:960-964. 
Gaudêncio CAA et al. 1990. População de plantas de soja no sistema de semeadura direta para o Centro-Sul do Estado do Paraná. Londrina: Embrapa, CNPSo, 1990. 4p. (Comunicado Técnico, 47).

Gewehr E et al. 2014. Influência da População de Plantas: Caracterização Morfológica de Cultivares de Soja em Solos de Varzea sob Irrigação por Aspersão. In: Reunião de pesquisa da soja da região sul, 40., Pelotas, 2014. Atas e Resumos. Pelotas: Embrapa Clima Temperado, 2014. $473 \mathrm{p}$.

Güllüllüoglu L et al. 2016. The effects of twin-row planting pattern and plant population on seed yield and yield components of soybean at late double-cropped planting in Cukurova region. Turkish Journal of Field Crops 21:59-65.

Hanna S et al. 2008. Fungicide application timing ad row spacing effect on soybean canopy penetration and grain yield. Agronomy Journal 100:1488-1492.

Heiffig LS et al. 2006. Fechamento e índice de área foliar da cultura da soja em diferentes arranjos espaciais. Bragantia 65:285-295.

Heitholt JJ et al. 1986. Characteristics of reproductive abortion in soybean. Crop Science 26:589-595.

Lima SF et al. 2012. Efeito da semeadura em linhas cruzadas sobre a produtividade de grãos e severidade da ferrugem asiática da soja. Bioscience Journal 28:954-962.

Ludwig MP et al. 2010. Características morfológicas de cultivares de soja convencionais e Roundup Ready TM em função da época e densidade de semeadura. Ciência Rural 40:759-767.

Novacek MJ et al. 2013. Twin Rows Minimally Impact Irrigated Maize Yield, Morphology, and Lodging. Crop Economics, Production \& Management 105:268-276.

Mattioni F et al. 2008. Arranjos espaciais, plantas concorrentes e características agronômicas da soja (Glycine max (Linn) Merril) em cultivo orgânico. Revista Brasileira de Agrociência 14:21-32.

Peixoto CP et al. 2000. Épocas de semeadura e densidade de plantas de soja: I. Componentes da produção e rendimentos de grãos. Piracicaba: Scientia Agricola 57:89-96.

Pereira Júnior $\mathrm{P}$ et al. 2010. Efeito de doses de silício sobre a produtividade e características agronômicas da soja [Glycine max (L.) Merrill]. Ciência e Agrotecnologia 34:908-913.

Pires JLF et al. 2000. Efeito de populações e espaçamentos sobre o potencial de rendimento da soja durante a ontogenia. Pesquisa Agropecuária Brasileira 35:1541- 1547.

Procópio SO et al 2013 Plantio cruzado na cultura da soja utilizando uma cultivar de hábito de crescimento indeterminado. Revista de Ciências Agrárias 56: 319-325.

Rambo L. 2004. Estimativa do potencial de rendimento por estrato do dossel da soja, em diferentes arranjos de plantas. 2004. Tese (Doutorado) Universidade Federal do Rio Grande do Sul (UFRGS).

Rambo L et al. 2003. Rendimento dos grãos de soja em função do arranjo de plantas. Ciência Rural 33:405-411.

Santos HG et al. 2006. Sistema brasileiro de classificação de solos. 2 ed. Rio de Janeiro: Embrapa Solos. 306p

SAS - Statistical Analysis System. 2013. GETTING Started with the SAS ${ }^{\circledR}$ Learning Edition. Cary, NC: SAS Institute 81p.

Shaw RH and Weber CR. 1967. Effects of canopy arrangements on light interception and yield of soybeans. Agronomy Journal 59:155-159.

Sellers PJ et al. 1994. A global 10,10 NDVI data set for climate studies. Part 2--the adjustment of the NDVI and generation of global fields of terrestrial biophysical parameters.

International Journal of Remote Sensing 15:3519-3545.

Shibles RM and Weber CR. 1967. Leaf area, solar radiation interceptation and dry matter production by soybeans. Crop Science 5:155-159.

Taiz L et al. 2017. Fisiologia e desenvolvimento vegetal. 6.ed. Porto Alegre: Artmed, 888 p.

Tourino MCC et al. 2002. Espaçamento, densidade e uniformidade de semeadura na produtividade e características agronômicas da soja. Pesquisa Agropecuária Brasileira 37:1071-1077.

Urben Filho and Souza PIM. 1993. Manejo da cultura da soja sob cerrado: época, densidade e profundidade de semeadura. In: Arantes NE e Souza PIM. (Ed.) Cultura da soja nos cerrados. Piracicaba: POTAFOS. pp.267-298. 